\title{
Construction of Plastic Parts on CNC Engraving Machines and 3D Printers
}

\author{
DAN PRODAN ${ }^{1}$, ANCA BUCURESTEANU ${ }^{1}$, ADRIAN MOTOMANCEA ${ }^{2 *}$ \\ ${ }^{1}$ University Politehnica of Bucharest, Department of Machines and Production Systems, 313 Splaiul Independenei, 060042, \\ Bucharest, Romania \\ ${ }^{2}$ University Politehnica of Bucharest, Department of Mechanics, 313 Splaiul Independenei, 060042, Bucharest, Romania
}

\begin{abstract}
This work presents some of researches performed by the authors on execution of plastic parts required for repair works specific to certain machines and plants. Authors focused especially on the repair and reconditioning of certain assemblies which include various machine parts: special spacers, machine-tools guides and toothed gears. Methods shown herein are very simple, accessible even to small workshop and they do not require special equipment, thereby involving minimal expenses. The use of simple programs allow fast and low-cost execution of parts with an accurately determined geometry.
\end{abstract}

Keywords: plastic guides, plastic toothed gears, guide elements, CNC machine processing.

CNC engraving machines are usually represented by mini CNC machine-tools, in most cases gantry milling machines with movable load $[2,3,5,9]$. Figure 1 shows the machine used by authors.

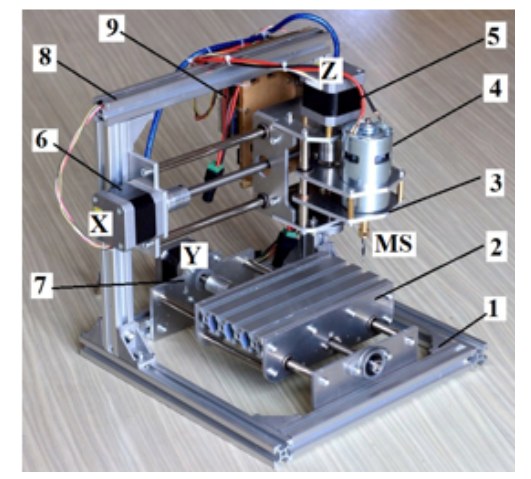

Fig.1. T8 DIY PCB CNC Engraving Machine

Structure of machine 1 is made of aluminum profiles. The stock part is fastened onto table 2 with brackets. This table can move with the feed kinematic chain 7. The travel direction is the $Y$ axis $[2,3]$. Feed kinematic chain 6 is fastened to portal 8 , which moves the work unit 3 , for with feed and / or positioning movements on the $X$ axis. The work unit 3 also includes the feed kinematic chain 5 corresponding to $Z$ axis and the main kinematic chain 4. This chain is direct drive -type, including an electric motor and the main shaft (MS). Each of the three feed kinematic chains corresponding to $X, Y$ and $Z$ axes include a stepper electric motor, precision screws and nuts with return backlash compensation systems [1-5]. The installed power is of $80 \mathrm{~W}$, and the machine is powered from electric module 9 at a voltage of 24V. The control is achieved with a regular computer (desktop or laptop). The milling and positioning accuracy on the three axes is of $0.1 \mathrm{~mm}$.

Considering these features, this machine may execute cutting works for materials like: hard wood, plastic, rubber, cardboard/paper.

3D printers allow execution of parts by laying down successive layers of material using specific programs [9]. figure 2 shows a 3D printer.

This machine is built on a frame-based structure 1 . The material is deposited on plate 2 (borosilicate glass). This plate is set on the printing bed 9 and it is moved on $Y$ axis using feed kinematic chain 7 , which includes an electric motor and toothed belt drive. The travel on X axis is provided
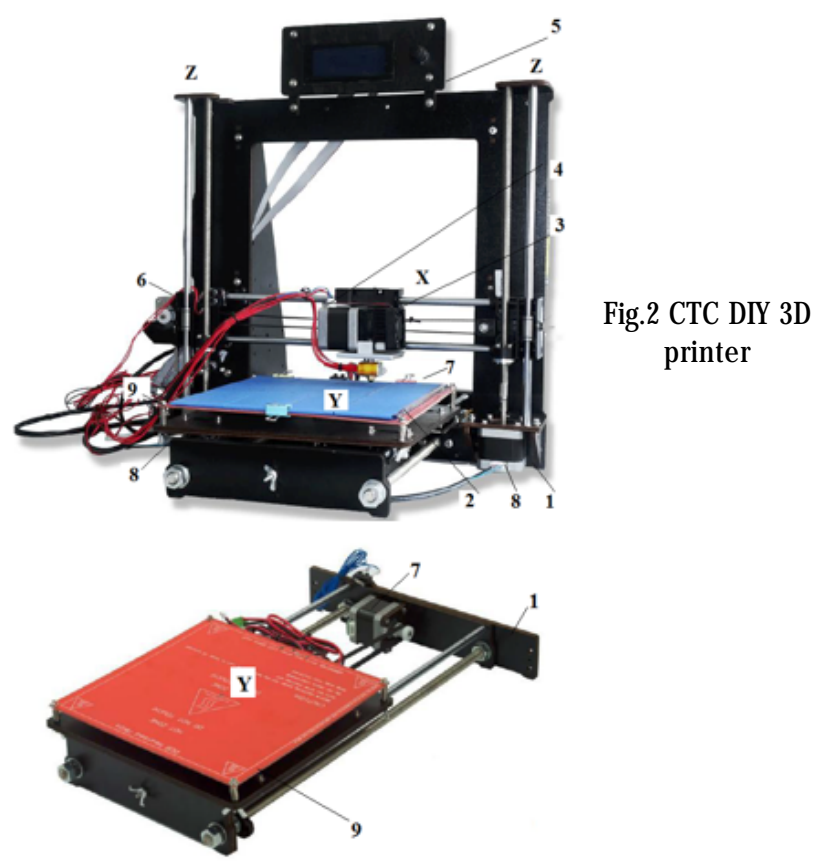

with the feed kinematic chain 6 , which has the same structure as the kinematic chain 7 . The skid 3 travels on the $X$ axis. The skid incorporates the extrusion head 4 , which includes the heating/cooling system, the material nozzle, the temperature sensor, the rollers and the material feed. Incremental positioning on $Z$ axis is achieved with two identical feed kinematic chains 8. They include motors, couplings and screw/backlash-free nut systems. This machine is controlled with a PC (personal computer), while process initialization and control are achieved using the display screen 5 . The material used by authors is a filament type PLA $\varnothing 1.75 \mathrm{~mm}$. This material has the density of $1.25 \mathrm{~g} / \mathrm{cm}^{3}\left(21.5^{\circ} \mathrm{C}\right)$ and it is extruded at a temperature in the range $190-225^{\circ} \mathrm{C}$.

On repairs or reconditioning works [6] on certain machines, it was found that certain plastic machine parts are deteriorated or even completely damaged. Replacement of these parts with spare parts provided by specialized companies may be an unfeasible solution, due to absence of such parts or to extended delivery times. In such cases, the intended parts may be manufactured using machines of the type shown above. 


\begin{tabular}{|c|c|c|c|c|c|}
\hline Density & Tensile & Operating & Operating & Relative speed & Operating \\
{$\left[\mathrm{g} / \mathrm{cm}^{3}\right]$} & strength & temperature & pressure \\
& {$\left[\mathrm{N} / \mathrm{mm}^{2}\right]$} & {$[\mathrm{m} / \mathrm{s}]$} & environment \\
& $80-100$ & {$[-30,+200]$} & $<400$ & $0-4$ & Oil/Water/Air \\
\hline $1.1-1.2$ & $\left.80 \mathrm{~cm}^{2}\right]$ & & \\
\hline
\end{tabular}

In a tirst stage, the Intended part Is drawn, and this drawing shall represent the starting point for the machine software. Selection of the method of execution of parts, i.e. cutting or deposition, depends on a series of factors, among which:

- the type of plastic used in manufacturing of the part. If this type is not compatible with 3D printing, then execution by cutting is required;

- accuracy of the part. Precision parts (guides, positioning elements, chain closing elements) shall be executed by cutting;

- in case of parts with a complex shape, that do not require a high accuracy (covers, ornaments, low-accuracy toothed gears, hand levers, bushings etc.), 3D printing shall be selected.

In case of complex parts (bearing housings, small enclosures, high-precision gears etc.), the stock part may be executed by printing with a certain addition on surfaces intended to be processed more accurately, and then these additions shall be removed by cutting.

\section{Execution of plastic support rings}

Many times, sealing elements for translational or rotational movement are installed with one or two support rings. These rings are executed from plastics (polyurethane) which meet conditions set forth in table 1.

Figure 3 shows several types of support rings that may be manufactured from materials consistent with requirements in table 1, using the machine shown in figure 1.

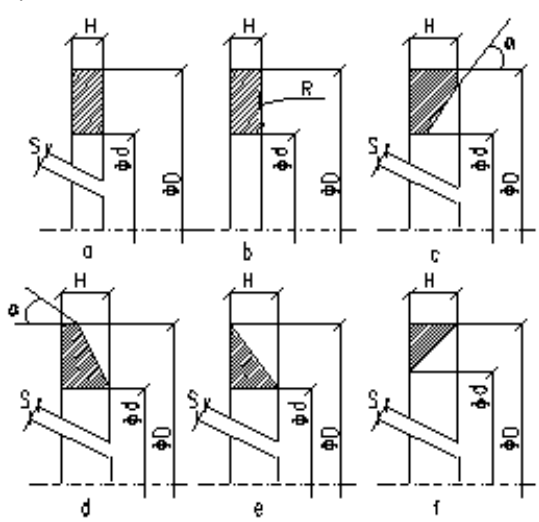

Fig. 3. Types of support rings

Diameters $D, d$ and sizes $H, R, S$ and á may be determined from catalogues or they may be measured on damaged parts. As an example, let's consider that we need to manufacture a support ring of the type shown in figure $3 b$, with the sizes shown in figure 4.

Based on the execution design, the software program required for processing may be elaborated. In this time, progress of processing may be followed on the computer screen as shown in figure 5 [9].

In the first stage, a spherical tool with a radius of $\mathrm{R}=$ $5 \mathrm{~mm}$ is used to execute the profile channel with a depth of $0.2 \mathrm{~mm}$ on $\varnothing 15$ diameter on a stock part with a thickness of $h=3 \mathrm{~mm}$.

Finally, using a cylindrical tool, diameters of $\Phi 10$ and $\Phi 20$ are cut.
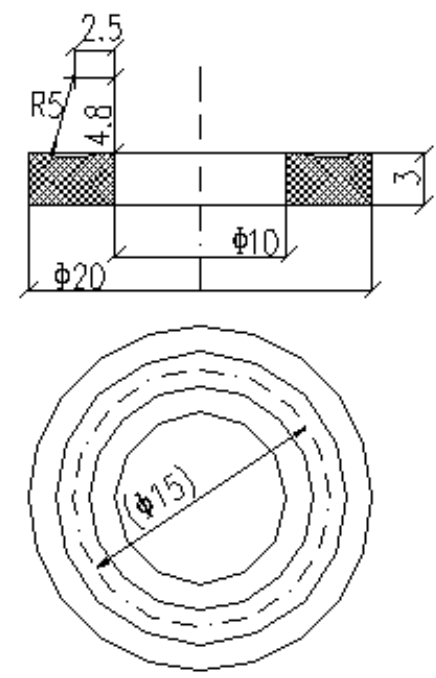

Fig. 4 Execution design for the support ring
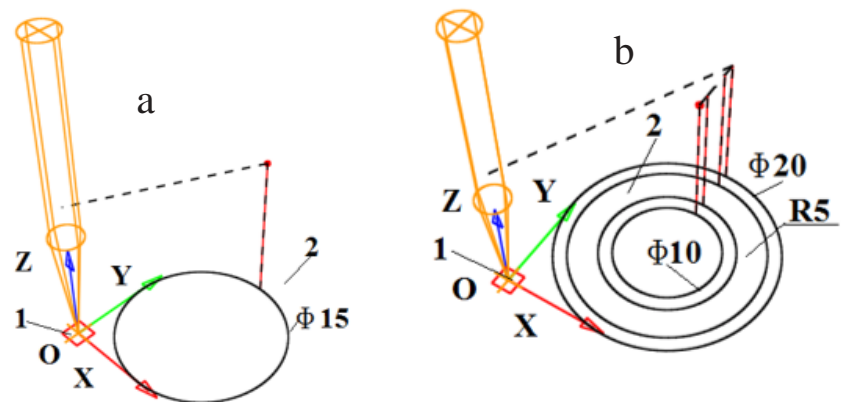

Fig. 5 Processing of the support ring

This is how the position of tool 1 and of stock part 2 in reference to the OXYZ reference may be followed.

Manufacture of plastic guides for machine tools

Guides of machine tools are intended to materialize generating lines, whether straight or circular, required for generation of processed surfaces [1-4]. During operation, they guide mobile elements like: skids, supports, glides etc. Guides also support these elements and provide movement accuracy. Guides must meet specific requirements like: precision, wear strength, stiffness, durability $[1,3,4]$. In case of heavy machine-tools [5], flat profile guides are used most often [2-4]. Plastics (polyamides) are successfully used in construction of guides for machine tools, replacing metals like bronze and cast iron [8,12,13].

The types of plastics most widely used for facing slideways are given below [10]:

a) PTFE-Polytetrafluorethylene based plastics with fillers such as, bronze, glass, graphite, molybdenum disulphide $\left(\mathrm{MoS}_{2}\right)$, ceramic or a mixture of them; the tradenames of the reinforced proprietary PTFE composites most widely used on machine tool slideways are the following: Turcite $B$, Rulon LR (formerly Rulon LD) and Rulon 142;

b) epoxi resin containing fillers; PTFE.

c) acetal resin with fillers such as $\mathrm{MoS}_{2}$, ceramic or 

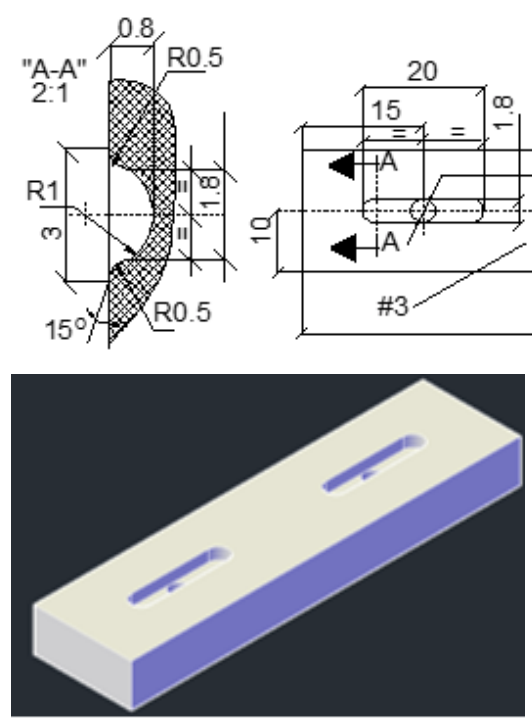

Fig. 6. Greasing channels executed in the slideway guide for intermittent greasing

Plastics destined for manufacturing of guides are delivered by specialized producers [9] as panels or strips.

Greasing channels for intermittent lubrication of slideways in machine tools may have varying shapes, based on the guide width $B$. Figure 6 shows a solution for guides that may be manufactured by cutting using an engraving machine.

Based on the execution design, using a profiled frontcylindrical tool, the greasing channel is executed on a depth of $0.8 \mathrm{~mm}$ in plates cut from stock material with $3 \mathrm{~mm}$ thickness, with sizes of $60 \times 20 \mathrm{~mm}^{2}$. After the channels are processed and the plates are fastened with special adhesives, it is recommended that they are touched up for execution of necessary corrections so that the corresponding number of contact spots is achieved [10,12]. Plastics used in execution of these elements allow very low speeds, mitigating the risk of occurrence of the stickslip effect [7].

\section{Execution of toothed gears with 3D printers}

In a first stage, before execution of parts using 3D printers, it is recommended that a sample part should be manufactured. Using this part, adjustments may be made for the temperature of extrusion head and mass, and also checks on geometrical features like: flatness, parallelism, squareness etc.

Figure 7 shows the manufactured sample part.

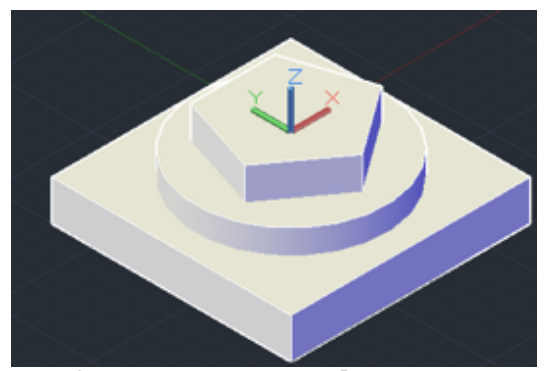

Fig. 7. Sample part manufactured with the $3 \mathrm{D}$ printer

After execution and measurement of this part, small adjustments may be performed, especially on the relative squareness between guides of $X, Y$ and $Z$ axis.

The toothed gear to be manufactured is shown in figure 8 and it has the following characteristics: $Z$ - number of teeth $20, \mathrm{~m}$ - module $2 \mathrm{~mm}, \xi$ - profile misalignment (evolvent) $0, B$ - width $5 \mathrm{~mm}$. This gear shall be driven by a shaft with 20mm diameter and a parallel key of $6 \times 6 \mathrm{~mm}^{2}$. The keyway has $a$ width of $b=6 \mathrm{~mm}$ and $a$ depth of $t=$ $2.5 \mathrm{~mm}$.

The teeth have an aligned evolvent profile and they are located on the reference diameter $D_{D}=40 \mathrm{~mm}$. The outer diameter of teeth is of $D_{E}=44 \mathrm{~mm}$, and the inner diameter

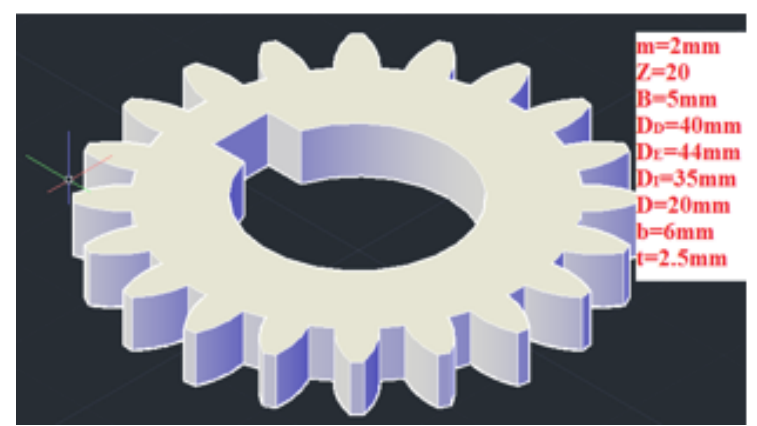

Fig. 8. 3D representation of the toothed gear to be manufactured with the printer

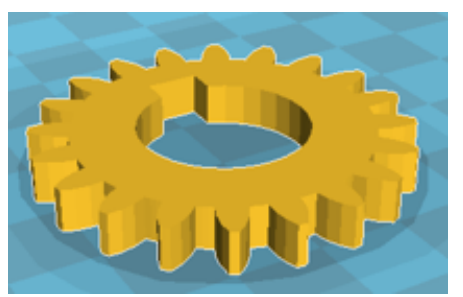

Fig. 9. Toothed gear to be manufactured with the $3 \mathrm{D}$ printer

$D_{1}=35 \mathrm{~mm}$. This drawing is imported in a specific format and it may be viewed as shown in figure 9 .

Following calculations, it is estimated that the processing time is of $44 \mathrm{~min}$.

Using the CURA software, the part design is set to the printer in a specific format (gcode) [9].

\section{Experimental part}

Parts shown in execution designs in figures 4 and 6 were manufactured on the engraving machine, and the sample part in figure 7 and the toothed gear shown in figures 8 and 9 was manufactured using the 3D printer.

Figure 10 shows the support ring executed from the $3 \mathrm{~mm}$ thickness plate. The total processing time was of app. $15 \mathrm{~min}$. This time also includes cutting-off the two diameters ( $\Phi 20$ and $\Phi 10)$. After processing, manual adjustments were minimal.

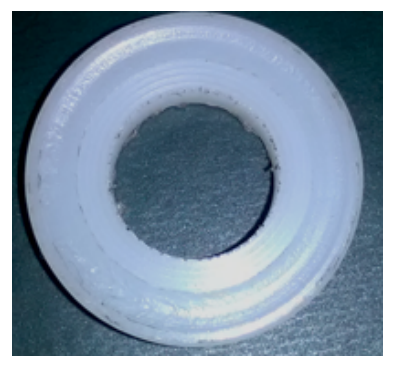

Fig. 10 Support ring manufactured with the engraving machine

The guide element shown in figure 6 required the use of a profiled tool and of a drill. The total processing time for channels was of app. $10 \mathrm{~min}$. We state that in this case no plate was cut-off $\left(60 \times 20 \mathrm{~mm}^{2}\right)$. The guide element manufactured is shown in figure 11 .

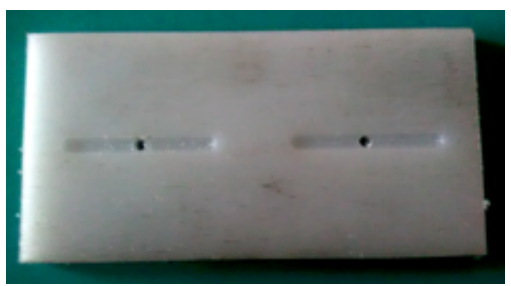

Fig. 11 Guide element with greasing channels manufactured with the engraving machine

For manufacture of the toothed gear, PLA filament was used. Temperature set in the extrusion head was of $208^{\circ} \mathrm{C}$, and the temperature of the deposition plate was adjusted to $67^{\circ} \mathrm{C}$.

Figure 12 shows the processing of the toothed gear.

Figure 13 shows the toothed gear manufactured. 


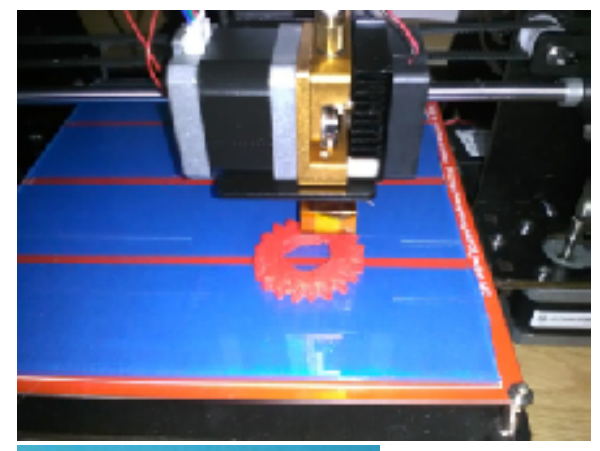

Fig. 12 Processing of the toothed gear using the $3 \mathrm{D}$ printer

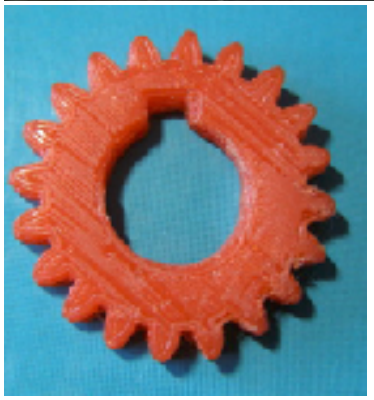

Fig. 13 Toothed gear manufactured with the 3D printer

The toothed gear is consistent with the driving conditions in respect with the conjugated gear, but the quality of tooth profile is below the quality achieved by cutting. In cases where repair works need to be performed quickly, until a replacement spare part is delivered by a possible supplier, the toothed gear may be executed using the 3D printer.

\section{Conclusions}

On the occasion of unforeseen, accidental or scheduled repairs, many times the plastic elements need to be replaced. In case the time needed to purchase such spare parts is available, it is preferable to purchase such elements from manufacturing companies. For cases where no suppliers are available or when time does not allow it, CNC engraving machines and / or 3D printers may be used. These machines, currently available at affordable prices, allow manufacture of parts with complex geometry (3D), in sizes of $200 \times 200 \times 150 \mathrm{~mm}^{3}$, using popular design software [11].

Cutting may be used to achieve surfaces that require higher accuracy and specific materials. This category includes guide elements. Structural parts: enclosures, bearing housings, toothed gears, covers etc. may be easily manufactured using 3D printers. Surfaces that require highprecision geometry or a high quality shall be finally executed by cutting with machine-tools. Execution of toothed gears using 3D printers, and also of other surfaces that cannot be achieved using conventional machine-tools, is of real use for machine repair or maintenance professionals. Thus, for execution of the toothed gear shown in figure 8, normally the following machine tools were required: a lathe, a milling machine (slotter) and a gear milling machine. The 3D printer may successfully replace all the above machines. The profile of teeth manufactured with this printer is less accurate than the profile acquired by cutting, but for ordinary transmission this may represent an acceptable solution.

\section{References}

1. TEIXIDO, C., J OUANNE, J.-C., BAUWE, B., CHAMBRAUD, P., IGNATIO, G., GUERIN, C., Guide de construction mecanique, Paris, Delagrave Edition, 2000, ISBN 2-206-08224.

2. PEROVIC, B., Handbuch Werkzeugmaschinen Berechung, Auslegung und Konstruktion, Munchen Wien, Carl Hanser Verlag, 2006, p. 583.

3. JOSHI, P.H., Machine Tools Handbook Design and Operation, New Delhi, Tata McGraw-Hill, 2007, p. 549.

4. BOTEZ, E., Masini-unelte. Bazele teoretice ale proiectarii. Organologia si precizia masinilor-unelte, Bucuresti, Editura Tehnica, 1978.

5. PRODAN, D., Masini - unelte grele. Sisteme mecanice si hidraulice, Bucuresti, Editura Printech, 2010.

6.PRODAN, D., MARINESCU, S., Refabricarea si modernizarea masinilor unelte, Bucuresti, Editura Tehnica, 2005.

7. HELMI, A.Y., HASSAN, E.-H., Machining Technology. Machine Tools and Operations, Florida, CRC PRESS, 2008.

8. COTETIU, R., Aspecte privind utilizarea poliamidelor în constructia utilajelor tehnologice, The Proceeding of $7^{\text {th }}$ National Symposium PRASIC'02, vol. I - Mecanisme si tribologie, Brasov, 2002.

9.*** www.halltech.com, www.aetnaplastics.com, www.tss.trelleborg. com, www.ctcprinter.com, www.MyDIYCNC.com.

10. DE CASTRO, H.F.F., A Study of the Plastics Coatings Used on Plain Slideways of Machine Tools, available at: http://www.abcm.org.br/ app/webroot/anais/cobef/2007/files/ 052001017.pdf.

11. BAWA, H.S., Manufacturing Process - I, New Delhi, Tata McGrawHill, 2004.

12. PRODAN, D, BUCURESTEANU, A., MOTOMANCEA, A., BALAN, E., Remanufacturing of Heavy Duty Machine Tools Guideways Plating with Plastic Materials, Mat. Plast., 53, no.4, 2016, p. 599

13. POPESCU, D., HADAR, A., COTET, C., Manufacturing of ABS P400 Solid Cellular Structures with Closed Cells By Fused Deposition Modeling as Rapid Prototyping Process, Mat. Plast., 43, no. 2, 2006, p. 175

$\overline{\text { Manuscript received: } 14.10 .2017}$ 